\title{
The socio-economic impact of pre-trial detention in Kenya, Mozambique and Zambia
}

\author{
Lukas Muntingh and Jean Redpath
}

\begin{abstract}
The presumed link between the rule of law and development suggests that an operational justice system is key to development. The research sought to understand and quantify how the decision to detain an accused person affects his or her socio-economic situation. Data was collected in Kenya, Mozambique and Zambia. The findings suggest that the use of the coercive power of the state exercised through the deprivation of an individual's liberty has serious socio-economic consequences. While detention pending trial is justifiable sometimes, we argue that it is over-used, frequently resulting in excessively long detention. The deprivation of liberty interferes with the ability of individuals to be agents of their own development, infringing on socio-economic rights of individuals and their dependents. States can justify such infringements only if their coercive power is used within the ambit of democratic and rights-respecting laws complying with human rights standards.
\end{abstract}

\section{Introduction'}

It is widely believed that well-functioning law and justice institutions and a government bound by the rule of law are important to economic, political and social development. ${ }^{2}$ The rule of law for the purpose of this article is understood to mean a system in which political and state actors do not take decisions arbitrarily but instead take decisions in accordance with the law. Most definitions would add a substantive component, for example that such laws should comply with international or continental human rights standards. 3

The presumed linkages between the rule of law and economic, political and social development have been poorly mapped out in theory and empirically. Initially, the discourse tended to be that of the "law and development movement" whose argument was that a rational system of law is necessary for economic development in order to permit

\footnotetext{
${ }^{1}$ The research on which this article is based was made possible with support from Open Society Initiative for Southern Africa (OSISA), in partnership with Open Society Initiative for Eastern Africa (OSIEA), the Open Society Justice Initiative (OSJI) and the United Nations Development Programme (UNDP).

${ }^{2}$ World Bank, 'Rule of Law and Development' http://go.worldbank.org/9OTC3P5070. Accessed 26 January 2016.

${ }^{3}$ For a discussion of definitions of the rule of law in the development context, see World Bank, 'Rule of Law as a Goal of Development Policy, http://go.worldbank.org/DZETJ85MD0. Accessed 26 January 2016.
} 
individuals to conduct their business with some degree of certainty. 4 The law and development movement was later discredited because of its tendency to adopt a UScentric legalistic approach to reform inappropriate to many developing contexts. 5

The law and development discourse was followed by a "judicial reform for development" approach. Adherents advocated for development-enhancing legal and judicial reform in developing countries through substantive and procedurally efficient rules of contract and property. The focus was again on a system of law in support of the enforcement of contracts. ${ }^{6}$ There was little focus on criminal justice institutions beyond the implied assumption that general maintenance of "law and order" is necessary to support development.

By contrast the World Bank Development Report of 2011 argued that war, crime and violence directly affect development. 7 The argument embraced in that report was that strengthening legitimate institutions and governance to break cycles of violence by reducing impunity for criminal acts is necessary to support economic development. This approach sees the role of the coercive power of the state in controlling crime and violence and establishing order as a necessary condition for development.

Parallel to these discourses, "the human-rights based approach to development" argued that human rights can give development goals a moral and legal basis and greater legitimacy, holding duty-bearers accountable for the failure to discharge their human rights obligations. ${ }^{8}$ This approach can be defined as a conceptual framework for the process of development "that is normatively based on international human rights standards and operationally directed to promoting and protecting human rights". ${ }^{9}$ In other words, in this approach the goals of development are informed by human rights standards toward enhancing their legitimacy.

A somewhat different conceptualisation of the idea that human rights and development are linked was pioneered by Amartya Sen, who argued that human rights enhance the capability of individuals to become agents of their own development. In Sen's view, freedom is both an end in itself and a means to development. ${ }^{10}$ This is particularly relevant in developing contexts such as those in Africa where the vast majority of economic activity is carried out by individuals operating on an entrepreneurial basis, rather than through state-controlled enterprises as is the case in some countries in Asia.

\footnotetext{
${ }^{4}$ See inter alia Law and Development Movement, World Bank Note, http://go.worldbank.org/F535AXQWE0. Accessed 26 January 2016. T. Ginsburg, "Does Law Matter for Economic Development? Evidence from East Asia”" Law \& Society Review, Vol. 34 , No. 3 (2000), pp. 829-856, p. 829.

${ }_{6}^{5}$ Ginsburg 2000, p. 830.

${ }_{7}^{6}$ Ginsburg 2000, p. 830.

7 World Bank, World Bank Development Report 2011, April 2011, http://siteresources.worldbank.org/INTWDRS/Resources/WDR2011_Full_Text.pdf. Accessed 21 January 2011.

${ }^{8}$ OHCHR 2006, p. 15.

${ }^{9}$ OHCHR 2006, p. 15.

${ }^{10}$ Sen 2000.
} 
We build on Sen's approach and argue that the use of the coercive power of formal criminal justice institutions exercised through the deprivation of individual liberty has a serious social and economic impact. While the deprivation of liberty is necessary and justifiable in some instances, we argue that it is used too often and frequently results in excessively long duration of pre-trial detention. The deprivation of individual liberty interferes with the ability of those individuals to be agents of their own development. Deprivation of liberty by the state in the application of criminal law and procedure infringes on the socio-economic rights of individuals and their dependents. States can justify such infringement of socio-economic rights only if their coercive power is used within the ambit of democratic and rights-respecting laws, and in compliance with human rights standards. This does, however, not mean that because the detention was lawful that there is no socio-economic infringement.

We seek to show that the deprivation of liberty by the state in the attempt to maintain "law and order" has a clear and measureable socio-economic impact on individuals and their dependents which is frequently disproportionate. We argue that states which seek to maximise development should minimise the conditions under which deprivation of liberty is lawful, and seek to reduce the total number of instances of deprivation of liberty, as well as their duration. The excessive use, frequently for minor offences and for extended periods, of pre-trial detention is counter-developmental and such negative consequences have not yet been adequately described as they are manifested in African contexts.

We question whether prioritising the "strengthening" of criminal justice institutions towards the maintenance of "law and order" is an appropriate or desirable development intervention in states which lack the resources to ensure appropriate and rightsrespecting use of their coercive power, given the inevitable impact of deprivation of liberty on individuals' ability to ensure their own development. We argue that in such contexts state power exerted by criminal justice institutions has a counter-developmental impact and the exercise of such power should accordingly be minimised.

The International Covenant on Economic, Social and Cultural Rights (ICESCR) requires States parties to take legislative and other measures 'with a view to achieving progressively the full realization of the rights recognised in the present Covenant'. ${ }^{11}$ The vagueness of certain offences, the manner in which the law is enforced and the lack of statutory protective measures for the detained accused, result in adverse socio-economic consequences for him or her and his or her dependents. While the maintenance of 'law and order' may come across as virtuous and often supported by zero-tolerance rhetoric from politicians and often with the approval of the broader public, we will present evidence in this article that the situation is more complex than it may appear. While the criminal justice system is concerned with individualisation of guilt, innocence and thus punishment, the impact of arrest and lengthy periods of detention is not limited to an individual, but has adverse socio-economic consequences affecting a network of people. In this reading, the

\footnotetext{
${ }^{11}$ International Covenant on Socio-Economic and Cultural Rights 1966, Art 2(1). See also ICSECR 'General Comment 31991 , para 7.
} 
state, assuming that it has an obligation towards socio-economic development, ${ }^{12}$ is required to enact laws and take other measures to prevent, or at least limit, adverse socio-economic consequences as a result of law enforcement. Civil and political rights, with specific reference to fair trial rights ${ }^{13}$ for the purposes here, and socio-economic rights are thus inter-dependent and indivisible. ${ }^{14}$

\section{Problem Description}

In most countries, persons accused of crimes may be held in detention before trial. The law permits this detention usually in order to guarantee the appearance of the accused at trial. In addition, in most countries a sentence of imprisonment usually follows a criminal conviction. These deprivations of liberty are considered to be justifiable where they are in compliance with fair trial rights such as those contained in instruments such as the International Covenant on Civil and Political Rights (ICCPR), ${ }^{15}$ which amongst others, requires a judicial officer to decide on continued detention and requires a prompt trial.

Yet across the world, it is believed that it is predominantly the poor and marginalised who end up in prisons either awaiting trial or after conviction, while it has been theorised, that their imprisonment has significant negative consequences for their families and households from which they originate. The UN Special Rapporteur on Extreme Poverty and Human Rights succinctly summarises the theorised socio-economic impact of pretrial detention in a recent report:

The economic and social costs of detention and incarceration can be devastating for persons living in poverty. Detention and incarceration can lead to loss of income and employment and often temporary or permanent withdrawal of social benefits. Their families, particularly their children, are also directly affected. Therefore, criminal justice systems predicated on detention and incarceration, even for minor non-violent crimes, can themselves represent a significant obstacle to access to justice for persons living in poverty. Those who are poor and vulnerable are likely to leave detention disproportionately financially, physically and personally disadvantaged. ${ }^{16}$

This article reports on research undertaken to demonstrate and quantify the socio- economic impact of pre-trial detention in particular and the complexity with which it plays out in three African countries, Kenya, Mozambique and Zambia.

The project was informed by the framework for socio-economic rights set out in the ICESCR. ${ }^{17}$ The rights relevant to this research in the ICESCR include:

\footnotetext{
${ }^{12}$ UNGA A/RES/41/128 (UN Declaration on the Right to Development) Art 1.

${ }^{13}$ International Covenant on Civil and Political Rights (ICESCR) 1966, Articles 9-15.

${ }^{14}$ Preamble to the ICSECR. General Comment 3 on the ICSECR para 8.

${ }^{15}$ International Covenant on Civil and Political Rights 1966, Articles 9-15.

${ }^{16} \mathrm{~A} / 67 / 278$ para 50.

${ }^{17}$ Kenya and Zambia have ratified the ICESCR but not Mozambique.
} 
- The equal right of men and women to pursue economic, social and cultural rights (art 3)

- The right to work and the duty of the state to take measures to enable people to

- $\quad$ access gainful employment (art 6)

- The right to just conditions of employment (art 7)

- The duty of the state to provide the widest possible protection to the family (art 10)

- The right to an adequate standard of living and to be free from hunger (art 11)

- The right to the enjoyment of the highest attainable standard of physical and mental health (art 12)

- The right to education (art 13).

The nature of the obligations on states set out by the ICESCR is not that states must ensure that every person has employment, social security, and the like, but rather that states should 'respect', 'protect' and 'fulfil' these socio-economic rights. The duty to 'respect' entails an obligation not to interfere with the resources of individuals, their freedom to find a job, or their freedom to take necessary action and to use their resources to satisfy needs.

This duty to respect socio-economic rights intersects with fair trial rights when states make and enforce criminal procedural and criminal laws. As this project sought to demonstrate, the decision to detain an accused person before trial almost invariably interferes with the resources of individuals, including individuals other than those being detained. Respect and protection of socio-economic rights by states in this would mean that criminal procedural laws and practices are designed and implemented in such a way as to ensure that the impact of interference with socio-economic rights on all persons is minimised, by ensuring that deprivation of liberty through detention of an accused only occurs when absolutely necessary and for the shortest possible duration. In General Comment 3 the Committee on Economic, Social and Cultural Rights noted that 'any retrogressive measures', and detention is of such a nature, 'would require the most careful consideration and would need to be fully justified by reference to the totality of the rights provided for in the Covenant and in the context of the full use of the maximum available resources.'

Some would argue that simply ensuring that fair trial rights are adhered to would ensure respect and protection of socio-economic rights. The right to a fair trial is a peremptory norm of international customary law ${ }^{18}$ and enshrined in article 14 of the International Covenant on Civil and Political Rights (ICCPR). Articles 9, 10 and 15 of the ICCPR inform the content of a fair trial rights and establish that:

- Arrested or detained persons must be brought promptly before a judicial officer and be entitled to trial within a reasonable time or to release;

${ }^{18}$ A peremptory norm is a fundamental principle from which no derogation is permitted. UN Human Rights Committee, General Comment 29, States of Emergency (article 4), CCPR/C/21/Rev.1/Add.11 (2001), and UN Human Rights Committee, General Comment 32: Right to Equality before Courts and Tribunals and to a Fair Trial, CCPR/C/GC/32 (23 August 2007), [54]. 
- It must not be the general rule that persons awaiting trial are detained in custody, but release may be subject to guarantees to appear for trial;

- There must be a fair and public hearing by an independent and impartial tribunal;

- There must be equality before the courts and tribunals;

- There must not be arbitrary detention;

- There must be restriction of the use of incommunicado detention;

- There is access for lawyers, doctors and family; and

- There is independent internal and external oversight. ${ }^{19}$

Violations of the right to a fair trial are likely to exacerbate the socio-economic impact on detainees and their associated households. While strict adherence to fair trial rights may work to limit the negative socio-economic impact of pre-trial detention, some impact is likely to occur even when fair trial rights have been observed.

There is thus an argument to be made that there is a duty on states to take into account socio-economic rights beyond adherence to fair trial rights. In at least one jurisdiction in Africa it has been held that when sentencing the primary caregiver of children, the impact on children's right to care must be taken into account. ${ }^{20}$ By extension, it could be argued that when detaining an accused before trial, or deciding to extend the detention of an accused who has already been detained for some time, the socio-economic impact on children and dependents must be taken into account. For example, in a number of African countries there exist offences for which bail is not permitted. ${ }^{21}$ Such laws which provide for non-bailable offences fail to adequately take into account the socioeconomic impact of detention. The research was undertaken to present empirical evidence on these impacts with a view to encouraging criminal and criminal procedural law reform.

It has been argued that the notion of freedom is indispensable for the protection of dignity'22 and that without freedom people are unable to develop their unique humanity and talents to the full extent of their potential.23 In her analysis of the right to freedom, Liebenberg refers to the work of Isaiah Berlin which was the basis for the approach to the right to freedom taken by the South African Constitutional Court as per Ackermann $J$ in the Ferreira case. Ackermann adopted a narrow view of the right to freedom and refers to a residual right to freedom, arguing that it means that individuals have a right not to have 'obstacles to possible choices and activities' placed in their way by the State. ${ }^{24}$ Liebenberg's

\footnotetext{
${ }^{19}$ UN General Assembly, Report of the Special Rapporteur on the question of torture and other cruel, inhuman or degrading treatment or punishment, A/56/156, 3 July 2001, [34]. Articles 6 and 7 of the AChHPR reflect ICCPR safeguards, and the ACHPR has provided further guidance on the content of the right to fair treatment in the Resolution on the Right to Recourse and Fair Trial (Res.4 (XI) 92) and the Principles and Guidelines on Rights to a Fair Trial and Legal Assistance in Africa (see also, Rights International v Nigeria, African Commission on Human and Peoples Rights, Communication no. 215/98, [29]). See also, Rights International v Nigeria, African Commission on Human and Peoples Rights, Communication no. 215/98, [29].

${ }^{20}$ S v M (CCT 53/06) [2007] ZACC 18.

${ }^{21}$ For example Tanzania, see Peter Joseph Chacha v the United Republic of Tanzania, Application No. 003/2012, African Court of Human and Peoples' Rights.

${ }^{22}$ Ferreira v Levin NO and Others; Vryenhoek and Others v Powell NO and Others (CCT5/95) [1995] ZACC 13; 1996 (1) SA 984 (CC); 1996 (1) BCLR 1 (6 December 1995) para 49.

${ }^{23}$ Liebenberg 2008, p. 155.

${ }^{24}$ Liebenberg 2008, p. 156 citing Ackermann J in Ferreira v Levin NO and Others; Vryenhoek and Others v Powell NO and Others, para 54.
} 
analysis of the Ferreira judgment argues for a broader conceptualisation of the right to freedom that would include, firstly, the human capacity for self-determination in the sense of developing the meaning and purpose of one's own life and making choices in accordance with these understandings'. Secondly, freedom not only includes the absence of direct interference, but also freedom from indirect forms of control which limit alternative routes of conduct available to other. 25

For the purposes of this article we will employ the narrower interpretation of the right of freedom and argue that the deprivation of liberty for the purposes of criminal law enforcement places such an obstacle in the way of individuals' right to freedom and consequently their pursuit of socio-economic well-being. Consequently states should take all measures to ensure such deprivation of liberty is indeed a measure of last resort and then for the shortest possible period.

\subsection{Methodology}

The study used data from (a) official records, (b) interviews with individuals awaiting trial in prisons and (c) interviews with household members associated with persons awaiting trial (d) previous studies. In addition to determining a demographic profile of detainees, the aim was to establish the existence of the following occurred, and if so, to quantify its extent:

- The loss of primary sources of income for households

- Unanticipated expenses incurred by households (prison visits/mailing/subsistence items for detainees)

- Financial support, child care and shelter burdens on extended family occasioned by the detention

- The burden of a parent's imprisonment experienced by children

- Psychological and social impact on detainees and their dependants

- Disrupted or reduced employment opportunities

- Diversion of family activities to a focus on incarceration and visitation

- Loss of family assets arising from the detention

- Social isolation and community aggression as a result of a family member being imprisoned.

- Exposure of pre-trial detainees to communicable or preventable diseases and ill-health

- The disruption of detainee's health.

The methodology envisaged for this study benefitted from the experience of similar studies conducted in West Africa, ${ }^{26}$ which relied on interviewing detainees and tracing their families for interviews. The West Africa study was ultimately forced to rely almost entirely on the evidence obtained from detainee interviews due to the difficulty experienced

\footnotetext{
${ }^{25}$ Liebenberg 2008, pp. 158-159.

UNDP-OSI Country Studies: The Socioeconomic Impact of Pretrial Detention available at http://www.undp.org/content/undp/en/home/librarypage/democratic-governance/access_to_justiceandruleoflaw/the-socioeconomicimpact-of-pretrial-detention/.
} 
in tracing relatives and dependents of detainees. The current study sought to increase the number of interviews with families and households by targeting visitors to the detainees.

To determine whether the sample of visitors needed to be supplemented by other interviews with affected non-visiting households, it was necessary to determine the extent to which detainees are visited. A sample of detainees was drawn from the admission registers and the extent to which detainees are visited was identified. If visiting was found to occur regularly with most or all detainees, an interview sample targeting visitors only was considered to be reasonably representative of detainees and affected households (this was the case in Mozambique). Where a significant number of detainees were found to be "notvisited", then a separate sample and process of tracing relatives or connected households who no longer visit or who never have visited, was undertaken, in order to attempt to ensure the sample also represents households and detainees who are not visited (this was the case in Kenya and Zambia).

For visitor interviews, it was intended that the detainee being visited would also be interviewed and the data linked with that of the interviewed visitor. Significant difficulties in this regard were experienced. Difficulties with linking may have been because of intervening releases from detention, transferrals, insufficient information supplied by the visitor, or insufficient information recorded on the questionnaires to permit the linking. In all three countries an insufficient number of detainees could be directly linked to their visitors.

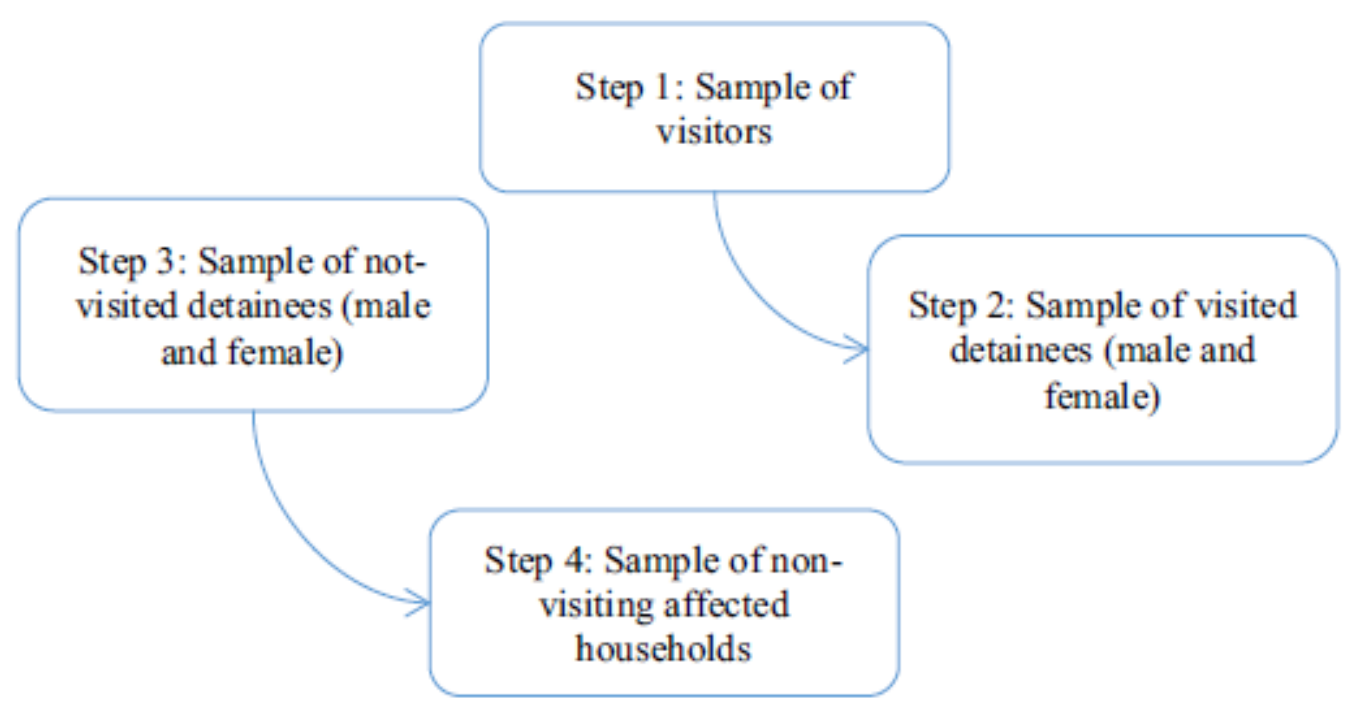

Fig. 1 Sampling methodology

Consequently in order to represent visited detainees, a random sample was drawn from the registers of detainees who had recently been visited.

In prisons where it was established that a significant minority of detainees fail to receive visits, a random sample of detainees from admission registers ("the detainee register 
sample") was undertaken (this was done in Kenya and Zambia). Amongst those sampled, only the "not-visited" detainees and families/households of detainees were traced, with the target number being determined by the ratio of visited to not-visited detainees. The project design is described in Fig. 1.

\subsubsection{Visitor Interview Selection Process}

In order to randomise visitor interviewees as much as possible, visitors were approached on different days of the week and different hours of the day during times when visiting is permitted, over a period of weeks. (Some prisons allocate different times for different section of the prison, which sometimes were determined by seriousness of offence, for visits.) The extent to which this process resulted in a truly representative sample of visitors is unclear, as is the extent to which refusals to interview may have demonstrated common trends. However, there is no reason to believe the process did not result in a representative sample of visitors.

\subsubsection{Detainee Interview Selection Process}

Prisons generally have a sequential handwritten register with the names of persons admitted on remand to the prison recorded in chronological order. From the register, fieldworkers were instructed to draw a randomised sample of 80 people going back 2 years. The questionnaire was then administered amongst the 80 selected (targeting a total of 30 interviews) who are still in detention. This sample was divided into "visited" and "not visited". If all detainees are visited, then the sample did not include a "not-visited" component. Should the process yield fewer than the target, fieldworkers were instructed to re-iterate the sampling until the target was reached. Selection was made based on admissions rather than current occupation profiles because occupation profiles tends to over-represent longer-term detainees. This research sought to generalise about all those detained pre-trial, including those detained for short periods of time.

\subsubsection{Traced Person Interview Selection Process}

The ratio of detainees who had been visited to those not visited by family/household members was determined through the sampling above. If a significant proportion of detainees were not recently visited, then an interview sample of "not-visited" detainees was carried out. These detainees provided details of the households, who were then traced for traced person interviews.

\subsubsection{Female Detainees}

The process was intended to be replicated in prisons holding female detainees. However some of the prisons selected had fewer than 30 female detainees at the time of conducting the research. Consequently all detainees were interviewed and attempts made to interview their households, whether through visitors or through tracing them.

\subsubsection{Total Interviews}

A total of 325 interviews were conducted as shown in Table 1 below. 
Because significantly different trends were found from country to country, the data was analysed per country.

Data was collected from the following prisons:

- Kenya: Nairobi Remand, Langata Female and Thika Main prisons

- Mozambique: Estabelecimento Penitenciario Provincial de Maputo, Estabelecimento Penitenciario Especial para Mulheres de Ndlavela and Estabelecimento Penitenciario Preventivo de Maputo.

- Zambia: Lusaka Central Prison and Kalomo State Prison.

\subsubsection{Register Data}

Demographic and detention duration data was drawn from registers, or derived from preexisting "pre-trial audits". This provided the admissions profiles for the detainees as well as a reliable estimate of the duration of detention. Where additional information was available regarding the composition of the pre-trial population at the time of data collection, this information was also recorded.

Table 1 Interviews carried out

\begin{tabular}{|c|c|c|c|c|c|c|c|c|c|}
\hline & \multicolumn{3}{|c|}{ Kenya } & \multicolumn{3}{|c|}{ Mozambique } & \multicolumn{3}{|c|}{ Zambia } \\
\hline & Male & Female & Total & Male & Female & Total & Male & Female & Total \\
\hline Visited detainees & 58 & 2 & 60 & 39 & 30 & 69 & 79 & 20 & 99 \\
\hline Not-visited detainees & 45 & 30 & 75 & 0 & 0 & 0 & 39 & 10 & 49 \\
\hline Total detainees & 103 & 32 & 135 & 39 & 30 & 69 & 118 & 30 & 148 \\
\hline Visitors & 58 & 0 & 58 & 39 & 30 & 69 & 70 & 22 & 92 \\
\hline Traced persons & 40 & 20 & 60 & 0 & 0 & 0 & 38 & 8 & 46 \\
\hline Total households & 98 & 20 & 118 & 39 & 30 & 69 & 108 & 30 & 138 \\
\hline
\end{tabular}

\subsubsection{Internal Validity of Data}

The study made extensive use of interviews and thus self-reporting. As far as was possible, data trends were compared to existing data (e.g. other studies and census data) as well as internal data to the study. In particular, trends reported by detainees were checked against trends reported by affected households. Nairobi Remand typically admits close to 10 ooo male remand detainees each year; Maputo has dropped from over 5000 male remand admissions in 2009 to 1300 in 2013; while Lusaka Remand typically admits more than 1000 male detainees each year.

\subsection{Findings}

The places of detention selected for the study provided insight into pre-trial detention trends and impacts in the greater urban areas of Nairobi, Maputo, and Lusaka. The research found that while there are significant commonalities observed between the three urban centres, there are also notable unique trends in socio-economic impact in each country. In common to all three countries and contrary to popular opinion, the majority of 
detainees were not social outcasts living on the margins of society, but rather economically active individuals residing at fixed addresses and contributing to the support of several dependents.

In Nairobi, Kenya, a pattern emerged where detainees are highly likely to be migrant workers, who are single or married with multiple dependents, living and working away from the family in the greater urban area in order to be able to provide an income to those in rural areas. Available information suggests they are unlikely to be recidivists (they did not report prior charges) and likely to be held on theft charges. Detainees are highly likely to spend some months in detention. Amongst female detainees, the pattern was predominantly of migrant domestic workers earning around or less than the minimum wage, also supporting dependants elsewhere, arrested for offences conceivably related to their former employment. Interviews with affected household members confirm the impact of the loss of the detainees' care and financial support and the stress and depression occasioned by their arrest; assets were sold, money was borrowed, income was lost. A significant proportion of detainees were held on unaffordable bail, which was an additional source of stress for respondents in affected households.

In Maputo, Mozambique, detainees tended to reside with their families and are integral to their families' emotional, social and economic well-being. The majority of detainees are of prime income-earning age and have some basic education, and live with their families. Their families are not wealthy and have incomes which are highly reliant on the income and non-monetary support formerly generated by the detainees. Women were again likely to engage in domestic work and be held on child-related offences. Many detainees were responsible for the entire household income: among men, more than two-thirds contributed the entire household income, while among women; more than $40 \%$ contributed the entire income. The continued incarceration of the detainee, in the majority of instances, more than halves the family income and places additional economic and social strain on the family, including the cost and burden of visiting the detainee over extended periods.

In Lusaka, Zambia, instances of exceptionally long duration of detention were observed with one in every ten detainees interviewed having been in custody for 4 years or longer. In many of these instances families had ceased to visit the detainees: the median duration of detention for those detainees linked to respondents not recently visited was 270 days, compared to 60 days for those who were visited by their families and friends. The median travel costs for a single visit represented almost one-sixth of median household income. Detainees were more likely than the Zambia average to be married, and tended to have slightly larger households than the Zambian average. Almost all were economically active and had education levels in line with the Zambian population; they were highly likely to speak a minority ethnic language. More than half of households were entirely reliant on the detainee's former contribution for total household income; more than half had to sell an asset and a third had to borrow money as a result of the detention. 
Common to all three sites, was thus evidence to support the contention that the decision to detain an accused person before trial almost invariably interferes with the resources of individuals, including individuals other than those being detained. The impact is felt by families and other households associated with the detainee, and where the detainee is female, impact on children in particular can be severe. Impact is generally immediate, but may have enduring negative consequences from which a household struggles to recover, particularly where the detention continues indefinitely. Different households have different levels of resources or access to resources which may also determine how they are able to respond to the problem of detention. There is little doubt that detention has a socio-economic impact; the findings suggest that the severity of the impact is in turn determined by preexisting socio-economic circumstances and extent of compliance with fair trial rights. While the phenomenon of pre-trial detention sets out with the same event-a person belonging to a household (or not) is imprisoned for a period of time-the results are extremely varied, flowing from a set of inherent characteristics or conditions, or from external factors. The list of factors described below attempts to identify some of the main drivers and relations between different variables and how they affect the socio-economic impact of pre-trial detention.

\subsection{Factors Affecting Nature and Extent of Socio-Economic Impact}

A household's vulnerability and resources impacts on how it experiences the impact of detention. The research points to a complex set of factors that interact to either intensify or ameliorate the socio-economic impact of pre-trial detention. These include the level of poverty of the household; the extent of prior reliance on the detainees' income or other contributions to the household; the number of dependents; the gender of the detainee; the number and age of children in the household; the duration and location of the detention, relative to the household; and the costs associated with the detention itself, such as providing food during police detention or attempting to secure legal representation.

Level of Poverty The financial and non-financial means of a household is fundamental to understanding the socio-economic impact of pre-trial detention. In all three countries household incomes of affected households was suggestive of poorer households. In Kenya, households had up to nine persons, with between 1 and 4 of these household members contributing to the respondent household cash income; yet the median total household income was only KSh 9000 (US\$ 99) ${ }^{27}$ - less than the minimum domestic worker wage in Kenya at the time. ${ }^{28}$ In Zambia, the median total household income was ZK700 (US\$50), while the minimum wage in Zambia in 2012 was ZK1132 (US\$81) for shop workers and ZK520 (US\$37) for domestic workers. In Mozambique, total household income for detainee households started at MT500 (US\$ 16)), with a median of MT3600 (US\$ 114), compared to the minimum wage in Mozambique, the lowest of which applies to the agricultural sector, is MT3010 (US\$ 95). Depending on the number of adults in the household, the medians here are suggestive of a significant proportion of detainee or dependent households

\footnotetext{
${ }^{27}$ All currency conversions were calculated in January 2015 when the full research reported was drafted.

${ }^{28}$ This is the median for the $75 \%$ of respondents who could provide detailed household income.
} 
living below the poverty line of US $\$ 1.90$ per adult per day. ${ }^{29}$ In Zambia $94 \%$ of families interviewed experienced a loss of income as a result of the detention; in Kenya $75 \%$, and in Mozambique 64\%. Thus most households already experiencing a marginal livelihood prior to detention are forced into deeper poverty and food insecurity by the detention, so that the detention negatively affects households' right to an adequate standard of living and adequate food (Article 11, ICESCR). In Kenya, this was more pronounced in relation to female detainees. Among respondents linked to female detainees, 65\% said they had less food as a result of the detention, compared to $35 \%$ among those linked with male detainees.

Some households were forced to incur debt, resulting in ongoing hardship. In Kenya some $39 \%$ of respondents said they had been forced to borrow from at least one lender in order to cover losses and the additional expenses caused by the detention, with the median amount borrowed being a third of the respondent household monthly income. In Mozambique some $34 \%$ of respondents said they were forced to borrow money in order to make up for the shortfall in income caused by the detention. The median amount borrowed was equivalent to a third of the minimum monthly wage. In Zambia $36 \%$ said they had to borrow, with the most common amount being ZK1500 (US\$107), more than double the median household income.

Households which do have some assets or savings, tend to use these to manage the detention situation, until those reserves are exhausted and the family is plunged (back) into marginality. Some $53 \%$ of respondents in Zambia said they had been forced to sell something, with $4 \%$ selling land or land rights. Some $22 \%$ of respondents in Kenya said they had been forced to sell at least one type of asset as a result of the losses caused by the detention. Up to three different types of items were sold, often at prices less than the true value of the asset. Data from Kenya indicates that in half of instances, items were sold for less than the respondents wished to sell them. The difference between asking and selling price in these instances ranged from KSh 150 (US\$ 1.66) to KSh 50,000 (US\$ 553), median KSh 3000 (US\$ 33). In other words the sale resulted in realising less than the item was worth.

Extent of Household Reliance on Detainee If the detainee is the main or sole income earner in the household and he or she is imprisoned it follows that the impact will be more severe. The research suggests that detainees were more likely than not to be the major contributors to household income. The median proportional detainee contribution to total household income in Kenya was 67\%, in Mozambique 70\%, and in Zambia $100 \%$. Detention results in the loss of such income, which is immediate and severe. The more income-earners a household has, the better able it will be to cope with the loss of income. But this research suggests there trends to be a reliance on one income earner, the detainee, for the overwhelming majority of total household income. This also points to the interesting possibility that it is the income-earning itself which places the earner at

\footnotetext{
${ }^{29}$ http://www.worldbank.org/en/topic/poverty/overview
} 
higher risk of detention. Furthermore, if the detainee is in formal employment it becomes increasingly likely that he or she will lose his or her employment the longer in custody. If self-employed, it is likely that the detainee will lose the business client base unless there is a household member that can step into his or her shoes.

Number of Dependents and Household Size The greater the number of people and the higher the proportion of those who cannot generate income (such as children, the disabled and the aged) who are dependent or partially dependent on the detainee's income, the wider the socio-economic impact is likely to be. The results suggest that most detainees either live in large households (Zambia and Mozambique) or are supporting a number of dependents residing elsewhere (Kenya). Dependents tend to be of much younger or older age than the detainees. The data from Kenya, in particular, indicated that household size tended to be smaller than the number of financial dependents and the number of family members. This suggests that many pre-trial detainees tend to be economic migrants to Nairobi. Their "true" household (or dependent household) is located elsewhere, with the detainee effectively responsible for both. By contrast, in Mozambique more than half of detainees' own households comprised four or more members while in Zambia the median household size was six persons. Both the number of dependents and the number of household members gives the number of people directly impacted by the detention of the detainee.

Employability of Other Household Members Detention essentially results in the removal of a household member from that household for a shorter or longer period of time and this comes at a socio-economic cost that may be greater or lesser. In order to maintain the same or an approximate life style, this gap needs to be filled by another person. The extent to which other household members (or persons related to the household) can fill this gap will be an important factor in mitigating adverse socio-economic consequences of the detention. A household consisting of members with high employment potential or selfemployment potential will in all likelihood fare better than a household consisting predominantly of people with limited economic potential (e.g. children, elderly and disabled). In Kenya some $11 \%$ of respondents reported that at least one member of their household had a disability, $15 \%$ in Mozambique, and 5\% in Zambia. In Kenya, some $78 \%$ of male detainees and $100 \%$ of female detainees either had their own children or had other dependents. In Mozambique, the majority of detainees lived in households comprising two adults and a number of children. In Zambia, the median household size was 5, with most households comprising only two adults, suggesting that the norm is that there is only one adult available to compensate for the loss of the detainee while supporting three children .

Gender The research shows that gender is an important variable. While men are the numerical majority in pre-trial detention, the socio-economic impact is frequently felt by wives and mothers, who are more likely to visit and support detainees while attempting to maintain the family income. The majority of visitors to prisons are also female. They 
bear the burden of providing for the detainees' needs in detention, bringing food and other items at high costs of travel, while maintaining the family income.

In addition, the data consistently shows that while there are substantially fewer females in detention, the impact of their detention is more severe than that of males, and women also have fewer support structures whilst in detention as measured by the low number of visitors to them while they are in police detention and prison. In Kenya, female detainees typically earn less than the minimum wage at the time of arrest, supporting up to seven persons not living with them. In addition 1 in 8 said they were HIV positive, and none were visited in the last 2 weeks. Their state of health was also compromised at the time of arrest and in total, $75 \%$ were ill at the time of arrest or became ill thereafter. While the duration of detention for females (median $=66$ days) is about half of that for men (122 days), this is likely to be a function of the generally less serious charges against them (56\% of women were charged for theft). Male and female education profiles are similar, but $56 \%$ of female detainees in Kenya were domestic servants, placing them at the low end of the income scale.

In Nairobi the majority of female detainees are not Kikuyu, suggesting that they are employment migrants to Nairobi and surrounds. Furthermore indicative of this is that $86 \%$ of detainees lived on their own. All female detainees earned more than the poverty level, and half of female detainees earned at least the minimum wage for domestic work. More than $80 \%$ of female detainees had at least one child and nearly three quarters supported a person that was not their child. All of the women had either a child of their own or another dependant. The general profile would thus be that the women work in Nairobi and financially support their children and other dependents in the village. Noting that $43 \%$ of women are detained for theft by servant, it is almost guaranteed that they will lose their employment in addition to the impact of the deprivation of liberty.

When a woman is imprisoned, the social impact is frequently keenly felt by her children, as well as other children she cared for. In Kenya, all (100\%) of the female detainees had either a child of their own or another dependant. Some $81 \%$ of female detainees said they had their own children, with as much as $9 \%$ having 5 or more children. ${ }^{30}$ Some $72 \%$ of the female detainees interviewed said they had dependents other than their own children. As indicated above, households linked to female detainee were more likely to indicate food insecurity as a result of the detention. Some $32 \%$ of respondents linked to female detainees compared to $3 \%$ for male detainees said children had been forced to relocate as a result of the detention. Female detainees tend to make substantial non-financial contributions to households. In Kenya it was found that $50 \%$ of females cared for children and some 53\% cleaned house. In Mozambique some $37 \%$ of female detainees were reported to clean the house, $33 \%$ caring for children, $10 \%$ mentioned food or farm production, and $7 \%$ cooking. Male detainees also made significant non-financial

\footnotetext{
${ }^{30}$ Some $31 \%$ had one child, $13 \%$ had two children, $13 \%$ had three children, $16 \%$ had four children, and $9 \%$ had five or more children.
} 
contributions to household income, but these were more focussed on food production and maintenance of the residential structure.

The qualitative impact of detention on women (and thus their dependents) is severe, noting health concerns, social stigmatisation, emotional impact, financial impact, and relocation of family and children.

Children Children are extremely vulnerable to negative changes in the socio-economic position of the household. This is manifested in a number of ways, such as decreased access to schooling (the household can no longer afford school fees or the child drops out of school to earn money), relocation to relatives or friends, food insecurity, general insecurity, lack of or limited supervision by adults and so forth. It may also happen that older children are removed from school to take care of younger children and to perform the duties previously performed by the detainee. Children are therefore affected by the loss of financial and non-financial support services previously rendered by the detainee and affected by the detention. In Kenya, some $16 \%$ (20\% of those who had children in the household) said that the children in the household were forced to move as a result of the detention; 11\% of households with children reported that the children's behaviour had been adversely affected by the detention; $11 \%$ reported that the children missed school, while $3 \%$ reported that the children dropped out of school. The detention thus interfered with the right of these children to education (Article 13, ICESCR).In Mozambique, some 13\% said the children in their household were forced to relocate and live with another relative as a result of the detention, while in Zambia 13\% referred to a child having to relocate .

Other Functions in the Household Other impacts of the detention will to a large extent be determined by how central or not the detainee was to the household's well-being. If the detainee was an occasional visitor, made a small financial contribution and rendered minimal or no non-financial support services and are rarely visited, it follows that the impact will be less. However, if the detainee was the head of the household, the main income earner, enabled a range of non-financial support services and so forth, the impact will be more severe. In all three countries it was found that the majority of detainees were the household head: Kenya-males $81 \%$ and females 63\%; Mozambique-males $81 \%$ and females 53\%; Zambia- males $90 \%$ and females $43 \%$. The implication of his or her detention is that somebody else must now generate the income and render the non-financial support service, or it is lost. This also links up with the composition of the household. For example, if a husband is detained leaving behind an eight-month pregnant wife with two young children, the impact will different when there are two children age 16 and 17 years who may be in a position to support their mother to generate an income and take over some functions of the father.

The Cost of Visiting and Supporting the Detention The detention of household members brings new, direct and unplanned costs for a household. Visits are associated with costs such as transport for the visit, food, other materials (e.g. soap), clothing, medicine and so forth. Securing private legal aid-or attempting to do so-or assistance from a state 
institution (e.g. Human Rights Commission) may also result in costs. Gathering cash for bail, borrowing money, using savings or paying a bribe are further costs associated with detention. Pre-trial detention is therefore not only about losing financial and non-financial contribution, but also about incurring new and unplanned for expenses. Presumably, the longer detention continues, the higher the total of these expenses will be-until the family is forced to cease incurring these expenses in order to survive.

Visiting a person in prison adds an important new expense to households and the costs are not insignificant. The median travel costs were found to be as follows: Kenya-US\$ 2.76; Mozambique-US\$1.27, and Zambia US\$ 17.00. Travelling to a prison also consumes time that could have been used more productively, for example for economic activity. The regularity of visits, as assessed by the majority of respondents ranged from once per week in Kenya and once per month in Mozambique. The median one-way durations were recorded as listed here: Kenya- $90 \mathrm{~min}$; Mozambique-120 min; and Zambia-90 min. In respect of both the cost of visits and duration, the medians mask the maximum values. For example, the maximum travel cost for one Mozambican respondent was US\$ 713, as the person had to travel from South Africa to Mozambique. Similarly, in respect of travel time duration a maximum value of $48 \mathrm{~h}$ was recorded in Kenya.

Visitors also brought food to the prisons and in Mozambique the median value of food brought to prisons by some $44 \%$ of respondents, was US\$ 3.27. In Zambia detainees were more dependent on food brought by family members and this was done by $88 \%$ of respondents with a median value of US $\$ 11.90$ per visit. In Kenya visitors are prohibited from bringing cooked food, where instead $34 \%$ of respondents brought cash, with a median value of KSh30o (US\$3.32). Pre-trial detainees are highly dependent on cash in order to improve their conditions of detention and diet, by buying items from the prison shop. In Mozambique $15 \%$ of respondents brought cash on visits to the detainee with a median value of US\$ 3.17. Some $20 \%$ of Zambian visitors brought cash to detainees with a median value of US\$ 31.75 . Some brought cash at every visit, some had only done so once.

Table 2 Estimated cost of prison visits in Zambia

\begin{tabular}{lcrc}
\hline Item & Value ZK & \multicolumn{1}{l}{ US\$ } & Percentage \\
\hline Household income & 700.0 & $\$ 111.11$ & 100.0 \\
Travel cost & 120.0 & $\$ 19.05$ & 17.1 \\
Other items & 23.5 & $\$ 3.73$ & 3.4 \\
Food & 75.0 & $\$ 11.90$ & 10.7 \\
Total & 218.5 & $\$ 34.68$ & 31.2 \\
Balance of income & 481.5 & $\$ 76.43$ & 68.8 \\
\hline
\end{tabular}

In Kenya and Mozambique 3\% of respondents said that they had brought cash to pay bribes; these bribes were generally of relatively low value; i.e. under US $\$ 40.00$. Table 2 presents a 
somewhat simplified example, based on Zambian data, of the median costs of visits compared against the median household income as there are many permutations possible. Nonetheless, it points to the substantial cost of visits to prison. It is also assumed that the household is still able to sustain the median income of US\$ 111, which is more than likely not the case. However, the calculations show that the cost of a visit may be as high as a third of median household income. From the calculations items brought by fewer visitors such as cash (20\% brought a median cash amount of ZK 200 (US\$ 31.75)) and clothing (43\% brought clothes with a median value of ZK 150 (US\$23.81)) were excluded. Substantial numbers of households had to borrow money in order to cover additional expenses and to make up for the loss in income previously earned by the detainee or foregone by the visitor while visiting.

Health The research found that while large proportions of detainees were ill at the time of arrest, an increased proportion was ill during detention. While this had adverse consequences for them individually during detention, it may also hold longer term consequences for them and the households they return to upon release as it may impact on their socio-economic potential. In this regard, HIV-positive detainees may suffer more severe consequences under poor conditions of detention and limited medical treatment. It should be noted that the Committee on Economic Social and Cultural Rights in General Comment 14 emphasised the need for states to ensure access to health care services and goods to vulnerable and marginalised groups, including prisoners and detainees. ${ }^{31}$

In Kenya $75 \%$ of female detainees were either ill at arrest or became ill in prison or both. Of those who were ill at arrest, $69 \%$ developed additional illnesses while in prison. ${ }^{32}$ Some $77 \%$ of male detainees said they subsequently fell ill while in prison.33 In Mozambique $37 \%$ of detainees said they were ill or became ill during imprisonment; $47 \%$ of female detainees and $28 \%$ of male detainees. The most common illness in Mozambique while in prison was malaria (12\%). In Zambia $25 \%$ of detainees said they experienced ill health while in prison. After entering prison, some $11 \%$ had malaria, $2 \%$ had ulcers, $2 \%$ had stomach pains, $2 \%$ said they were HIV positive, and $2 \%$ had back pains. Access to medical treatment was limited. In Kenya $52 \%$ of male detainees said they received treatment in prison and only $52 \%$ of this group said the treatment they were given, helped. The situation in Mozambique was markedly better, with $92 \%$ of those needing health care being able to access it and 80\% saying that it helped. Data on access to and the effectiveness of medical care in Zambia was not collected.

Given that nearly all prisoners will sooner or later be released, poor health care services and poor conditions of detention create significant risks to the community in general and specifically the households to which prisoners return.

\footnotetext{
${ }^{31}$ UN Committee on ESCR General Comment No 14, UN Doc E/C/12/2000/4.

${ }^{32}$ Illnesses mentioned were diarrhoea and vomiting (15\%), chest pains and pneumonia (12\%), malaria (9\%), skin diseases (6\%), toothache $(6 \%)$, weakness and headache $(6 \%)$, backache $(3 \%)$, and eye problems $(3 \%)$.

${ }^{33}$ Malaria (17\%), skin disease, rashes, "spores" (17\%), chest complaints or pneumonia (13\%), cold or flu or coughs (7\%), typhoid $(3 \%)$, diarrhoea $(3 \%)$, tuberculosis $(3 \%)$, eye problems $(3 \%)$, ulcers $(3 \%)$, fainted, or falling down $(2 \%)$, headache $(2 \%)$, spine and neck pains $(2 \%)$, epilepsy (1\%), joint pains (2\%), cancer (1\%), toothache (1\%), high blood pressure (1\%), asthma (1\%) and allergy (1\%).
} 
Existence of Support Structures It was particularly observed in Kenya where a notable proportion of women were economic migrants to the capital where they lived on their own and were remitting funds to households outside Nairobi. Having a spouse appears to be an important factor. The extent to which a detainee can call upon support structures during detention will have an important impact on their access to food, cash (and bail), medicine, access to legal representation and emotional support. At the same time it was noted that detention had a negative impact on social, family and spousal relations for a large proportion of households.

Social Impact of Detention The strength and health of relationships that detainees have with family members and friends has a significant influence on how they experience detention as this manifests in, for example, frequency of visits, resources brought to the detainee and general emotional support. The preceding paragraph alluded to material support rendered by families and to a lesser extent friends, colleagues and employers. Having an extensive support structure will in all likelihood have a positive impact on the experience of detention.

Kenyan detainees reported that, in general, relationships with significant persons deteriorated since their detention: $45 \%$ said relations with persons other than spouse deteriorated; $43 \%$ of male detainees and $72 \%$ of female detainees said the relationship with their spouse deteriorated. Male Mozambican detainees are the only group that does not fit the expected profile and $74 \%$ said that the relationship with their spouse had improved. However, $55 \%$ of female Mozambican detainees said the relationship with their spouse had deteriorated. One in ten Zambian detainees stated that significant relationships had deteriorated, but many also did not know if these relationships were in any way effected by their detention. The Zambia fieldworkers reported that a large number of detainees with children reported that the relationships with their children had deteriorated, but this was not quantified. Similarly it was reported that there was also deterioration in relations with the friends, especially for detainees who had been in detention for a long time. With regard to spouses, the impression of the Zambia fieldworkers was that more relationships had deteriorated than the ones that improved and at least four detainees were deserted by their wives.

\subsection{Exacerbation of Impact Through Fair Trial Rights Infringement}

In each of the three countries, infringements of both fair trial and socio-economic rights could be identified. In the three countries concerned, there is evidence to suggest that the failure to adhere to fair trial rights exacerbates the socio-economic impact.

\subsubsection{Lengthy Durations of Custody}

Article 14 of the ICCPR provides that trial must occur without undue delay, and article 9 provides that detained persons are entitled to trial or release within a reasonable time. In its jurisprudence the United Nations Human Rights Committee, the body responsible for monitoring compliance by States party to the ICCPR, has made it clear that detention which 
may be initially legal may become "arbitrary" if it is unduly prolonged or not subject to periodic review. 34 The longer the detention, the more likely socio-economic impacts are likely to take on a permanent nature.

In Kenya the durations of detention recorded suggest that half of those still detained in prison are likely to have been detained for 4 months or more, while a quarter will have endured 204 days (almost 7 months) or more. After such lengths of time the socioeconomic impacts on family are likely to have been compounded. The findings here suggest that only a minority of detainees are tried or released within 30 days in Kenya. In Zambia the admissions profile suggests that there is a high turnover of persons spending a short amount of time of remand in Lusaka Central, while at the same time a significant number spend years on remand. The duration of detention ranged from same day release to 1796 days. There was a range of medians for each of the prisons surveyed, ranging from 11 to 112 days. In Mozambique the admissions profile showed a range of $0-655$ days (1.8 years) with a median of 66 days (2.2 months).

Torture The African Charter for Human and Peoples' Rights prohibits torture in Article 5. Torture is defined in Article 1 of the Convention against Torture.35 The right not to be subjected to torture and other ill-treatment is a non-derogable right; no one may be subjected to torture and other ill-treatment under any circumstance, including during times of war or public emergency. The prohibition of torture and other ill-treatment is also a rule of international customary law: it is regarded as so absolute and universally accepted that even states which have not ratified any of the international treaties that explicitly prohibit torture and other ill-treatment may not use torture. ${ }^{36}$

In Kenya $16 \%$ of male and $3 \%$ of female detainees reported that they had been assaulted whilst in custody. The overwhelming majority of males who were assaulted (80\%) said that they were assaulted by prison officials. Of more concern is the fact that only one in five male detainees reported the assault, and that nothing happened as a result of the report. None of the women reported the assault. In Mozambique only $4 \%$ of detainees interviewed said they had been assaulted while in detention. This was $5 \%$ among men and $3 \%$ among women. Most commonly identified as the perpetrators were other detainees, followed by police. It is an encouraging finding that such low levels of assault were reported. Data in this regard was not collected in Zambia.

\footnotetext{
${ }^{34}$ de Zayas 2001, pp. 67-121. Also de Zayas 2003, pp. 215-277. See also Case No. 305/1988 (Van Alphen v. The Netherlands) UN Doc. A/45/40, Vol. 2, Annex IX, Sect. M, para. 5.8: "The drafting history of Article 9, paragraph 1, confirms that 'arbitrariness' is not to be equated with 'against the law', but must be interpreted more broadly to include elements of inappropriateness, injustice and lack of predictability. This means that remand in custody pursuant to lawful arrest must not only be lawful but reasonable in all the circumstances." Nowak 1993, p. 172.

${ }^{35}$ UNCAT Art 1 "any act by which severe pain or suffering, whether physical or mental, is intentionally inflicted on a person for such purposes as obtaining from him or a third person information or a confession, punishing him for an act he or a third person has committed or is suspected of having committed, or intimidating or coercing him or a third person, or for any reason based on discrimination of any kind, when such pain or suffering is inflicted by or at the instigation of or with the consent or acquiescence of a public official or other person acting in an official capacity".

36 (FC) and others (FC) v. Secretary of State for the Home Department (2004); A and others (FC) and others vs Secretary of State for the Home Department [2005] UKHL 71 para 33. See also R v. Bow Street Metropolitan Stipendiary Magistrate, Ex parte Pinochet Ugarte (No 3) [2000] 1 AC 147, 197-199; Prosecutor v. Furundzija ICTY (Trial Chamber) judgment of 10 December 1998 at paras $147-157$.
} 
Unaffordable Bail In Kenya it was found that $65 \%$ of detainees claimed they could not afford the bail amount set by the court and an assessment of these values does lend credence to a claim that bail is set at disproportionate amounts with the an aim to make it unaffordable. Despite the fact that women are more commonly detained for theft than men, women reported unaffordable bail amounts in much higher frequency than men; 97 versus $54 \%$, because men were more likely to be detained on non-bailable offences. Unaffordable bail amounts alluded to by detainees ranged from US $\$ 77$ to US $\$ 44300$ cash bail and US\$ 55370 bond. The most frequently mentioned amount was US\$2215, which applied to nearly one in five (17\%) of those who said they were still in detention because of the bail amount. The next most common amount was US\$ 1107 which applied to $15 \%$ of those who could not afford bail. The net result is that $32 \%$ of detainees who were granted bail, were granted an amount that is more than the annual median income of detainees; US\$ 96037 compared to US\$ 1107.

The data for Mozambique is sketchy as only $20 \%$ of male detainees interviewed had an amount for security recorded, which presumably they were unable to afford and thus remained in detention. The amounts ranged from US\$ 319 to US\$ 8240, with a median of US\$ 3800 . All of the amounts applied to theft or robbery charges. The security amounts recorded are far in excess of median earnings and more than three times the annual minimum wage. In Zambia, detailed information on affordable bail was not available, but when asked regarding bail, the most common response was that they were detained on nonbailable offences.

Access to Legal Assistance The extent to which detainees were able to access legal assistance varied greatly. In Kenya only $16 \%$ of detainees said they had received some form of legal assistance, with female detainees being much less likely to have received legal assistance-only $6 \%$ compared to $19 \%$ of male detainees. This may be because of the difference in charges, as almost half (48\%) of those who received legal assistance, were charged with murder. Those who did receive legal assistance received it from Legal Aid (39\%) and private lawyers (29\%). In Mozambique just over half (54\%) said they received legal assistance and $76 \%$ of those who received assistance said this was from the Instituto do Patrocínio e Assistência Jurídica (IPAJ), the state funded legal aid institute. In Zambia $26 \%$ of detainees said they had received some form of legal assistance, but that legal assistance did not succeed in securing their release.

Very little information was obtained about the cost of private legal assistance, but in Kenya this ranged from US\$ 223 to US\$3337, and in Mozambique from US\$ 64 to US\$ 792. Hiring a private attorney is simply not affordable to many detainees and their continued detention

${ }^{37}$ The monthly median income was reported to be US $\$ 80.00$ 
may thus be a direct result of their poverty as a lawyer may indeed launch a successful application for their conditional release. 38

Those detainees who did receive legal assistance were also not always satisfied with the quality of service, especially if this was from state-funded legal aid. For example, in Kenya more than $80 \%$ of detainees who had private lawyers said they were very useful, compared to only $38 \%$ of those who had Legal Aid lawyers expressing satisfaction. In Mozambique only $13 \%$ of detainees said the legal assistance from IPAJ was "very useful"; a third said it was "somewhat useful", and another third said they were "not very useful". When asked why, most referred to the slow progression of their case. Some $17 \%$ had made use of private lawyers and a third of them said it was "very useful". It is nonetheless encouraging that state funded legal assistance is far more accessible in Mozambique than in the other two countries.

\section{Conclusion}

The nature of the obligations on states set out in instruments such the ICESCR entails an obligation not to interfere with the resources of individuals, their freedom to find a job, nor their freedom to take necessary action and to use their resources to satisfy needs. Socioeconomic rights intersecting with fair trial rights means that criminal procedural laws and practices must be designed and implemented in such a way as to ensure that the impact of interference with socio-economic rights on all persons is minimised, so that detention of an accused only occurs when absolutely necessary and for the shortest possible duration.

The research undertaken sought to understand and quantify how the decision to detain an accused person affects socio-economic rights, that is, the resources of individuals, including individuals other than those being detained. Common to all three sites investigated, was evidence to support the contention that the decision to detain an accused person before trial almost invariably interferes with the resources of individuals, including individuals other than those being detained. The impact is felt by families and other households associated with the detainee, and where the detainee is female, impact on children in particular can be severe. Impact is generally immediate, but may have enduring negative consequences from which a household struggles to recover. The research points to a complex set of factors that interact to either intensify or ameliorate the socio-economic impact of pre-trial detention. These include the level of poverty of the household; the extent of prior reliance on the detainees' income or other contributions to the household; the number of dependents; the gender of the detainee; the number and age of

\footnotetext{
${ }^{38}$ All three jurisdictions allow for various forms of bail, bond and surety. However, in Zambia section 123 of the Criminal Procedure Code Act sets out offences that are not bailable. They include murder, treason, and any offence carrying a mandatory death penalty. Other offences are aggravated robbery and theft of motor vehicles if the accused has previously been convicted of the offence of theft of a motor vehicle. The State Security Act states that espionage is not a bailable offence. Lastly, people charged with offences related to drug trafficking or manufacturing of drugs under the Narcotic Drugs and Psychotropic Substances Act cannot be granted bail. (See Criminal Procedure Code Act No. 35 of 1993, as amended by Act No. 9 of 2005, Chapter 88 of the Laws of Zambia; Section 3 of the State Security Act No. 36 of 1969, as amended by Act No. 27 of 1985, Chapter 111 of the Laws of Zambia; and section 123(4) of the Criminal Procedure Code Act No. 35 of 1993, as amended by Act No. 9 of 2005, Chapter 88 of the Laws of Zambia. Section 43 of the Narcotic Drugs and Psychotropic Substances Act, No. 37 of 1993, as amended by Act No. 13 of 1994, Chapter 96 of the Laws of Zambia).
} 
children in the household; the duration and location of the detention, relative to the household; and the costs associated with the detention itself, such as providing food during police detention or attempting to secure legal representation.

In each of the three countries, infringements of both fair trial and socio-economic rights could be identified. In the three countries concerned, there is evidence to suggest that the failure to adhere to fair trial rights thus exacerbates the socio-economic impact. Lengthy periods of detention running to years in Zambia infringes the right to a fair trial without unreasonable delay; unaffordable bail in Kenya infringes the right to equality before the law; in Mozambique, not being taken to court to apply for bail infringes the right to challenge one's detention. In each case the infringement may have led to a detainee remaining in detention longer than they may otherwise have been done, thus increasing the socio-economic impact felt by families and associated households.

While respect for fair trial rights may ameliorate socio-economic impact, there is a need to recognise that even when fair trial rights are respected, there may be an additional need to take into account socio-economic impacts, in the way in which laws are made and implemented. Whether or not a country is signatory to the ICESCR, states should be aware of the ways in which state policies and practices may be aggravating and entrenching poverty and thus be counter-developmental.

The vast majority of pre-trial detainees are generally similar to most other people in their country, and tend to be integrally involved in supporting their families, whether financially or emotionally or in other ways, and enjoy the respect of society. Their absence has a measurable impact, frequently more than halving incomes, depleting savings, often plunging families into debt, and forcing the sale of assets. While some may be guilty of crimes, fair trial rights require that their cases be heard without undue delay, and that they be presumed innocent until they are tried and convicted. The evidence in this study suggests that the criminal procedural system metes out a "punishment" in the form of a socio-economic impact on detainees and their families, before conviction, and regardless of guilt or innocence.

Respect for socio-economic rights by states and awareness of poverty impacts would mean that criminal, and criminal procedural laws and practices are designed and implemented in such a way as to ensure that socio-economic impact on all persons is minimised. This may place an obligation on states to decriminalise trivial offences, to ensure alternative methods of securing attendance at trial are available, to ensure individuals are tried within a reasonable time, and, beyond simple compliance with fair trial rights, reconsider the appropriateness of pre-trial detention in the light of inevitable and severe impacts causing disproportionate harm to detainees and affected households.

Deprivation of liberty by the state in the attempt to maintain "law and order" has a clear and measureable socio-economic impact on individuals and their dependents which is frequently disproportionate to the alleged offence. Deprivation of liberty is thus counter- 
developmental. States which seek to maximise development should minimise the conditions under which deprivation of liberty is lawful, and seek to reduce the total number of instances of deprivation of liberty, as well as their duration. Prioritising the "strengthening" of criminal justice institutions towards the maintenance of "law and order" is not an appropriate or desirable development intervention in states which lack the resources to ensure appropriate and rights-respecting use of their coercive power, given the inevitable impact of deprivation of liberty on individuals' ability to ensure their own development. In such contexts state power exerted by criminal justice institutions has a counter-developmental impact and the exercise of such power should accordingly be minimised.

\section{Acknowledgements}

The research on which this article is based was made possible with support from Open Society Initiative for Southern Africa (OSISA), in partnership with Open Society Initiative for Eastern Africa (OSIEA), the Open Society Justice Initiative (OSJI) and the United Nations Development Programme (UNDP). 


\section{References}

\section{Journal Article}

Ginsburg T (2000) Does law matter for economic development? Evidence from East Asia. Law Soc Rev34(3):829-856

Liebenberg S (2008) The value of freedom in interpreting socio-economic rights. Acta Juridica Spec Edn, pp 149-176

\section{Book}

Nowak M (1993) UN Covenant on civil and political rights. CCPR commentary. N.P. Engel, Kehl-Strasbourg

Sen A (2000) Development as freedom. Anchor Books, New York

\section{Book Chapter}

De Zayas A (2001) The examination of individual complaints by the united nations human rights committee under the optional protocol to the international covenant on civil and political rights. In: Alfredsson $G$ et al (eds) International human rights monitoring mechanisms. Martinus Nijhof Publishers, The Hague, pp 67-121

De Zayas A (2003) Desarrollo jurisprudencial del Comite' de Derechos Humanos. In Piernas CJ (ed)

Iniciacio'n a la Pra'ctica en Derecho Internacional. Marcial Pons, Madrid, pp 215-277 Online Document

Office of the United Nations High Commissioner for Human Rights (2006) Frequently asked questions on a human rights-based approach to development cooperation http://www.ohchr.org/Documents/Publications/FAQen.pdf. Accessed 21 Jan 2011

United Nations Development Programme (2013) Country studies: the socioeconomic impact of pretrial detention.

http://www.undp.org/content/undp/en/home/librarypage/democraticgovernance/access_to_justiceandruleoflaw/the-socioeconomic-impact-of-pretrialdetention/. Accessed 21 Jan 2011

World Bank (2007) Law and development movement: world bank note. http://go.worldbank.org/F535AXQWEo. Accessed 26 Jan 2016

World Bank (2011) World bank development report 2011. http://siteresources.worldbank.org/INTWDRS/Resources/WDR2011_Full_Text.pdf. Accessed 21 Jan 2011

World Bank (2016) Rule of law and development. http://go.worldbank.org/9OTC3P5070. Accessed 26 Jan 2016

World Bank (2016) Poverty. http://www.worldbank.org/en/topic/poverty/overview. Accessed 26 Jan 2016

\section{International and regional instruments and case law}

African Charter on Human and Peoples' Rights, Adopted 27 June 1981, OAU Doc. CAB/LEG/67/3 rev.5, 21 I.L.M. 58 (1982), entered into force 21 October 1986

African Commission on Human and Peoples' Rights, Principles and Guidelines on Rights to a Fair Trial and Legal Assistance in Africa 
Committee on Economic, Social and Cultural Rights, General Comment 3, The nature of States parties' obligations (Fifth session, 1990), U.N. Doc. E/1991/23, annex III at 86 (1991), reprinted in Compilation of General Comments and General Recommendations Adopted by Human Rights Treaty Bodies, U.N. Doc. HRI/GEN/1/Rev.6 at 14 (2003)

International Covenant on Socio-Economic and Cultural Rights Adopted and opened for signature, ratification and accession by General Assembly resolution 2200A (XXI) of 16 December 1966

International Covenant on Socio-Economic and Cultural Rights 'General Comment 3' Adopted 1 January 1991, para 7

International Covenant on Civil and Political Rights, Adopted and opened for signature, ratification and accession by General Assembly resolution 2200A (XXI) of 16 December 1966, entry into force 23 March 1976

Peter Joseph Chacha v the United Republic of Tanzania, Application No. 003/2012, African Court of Human and Peoples' Rights

Prosecutor v. Furundzija ICTY (Trial Chamber) judgment of 10 December 1998

Rights International v Nigeria, African Commission on Human and Peoples Rights, Communication no. 215/98

UN Committee on ESCR General Comment No 14, UN Doc E/C/12/2000/4, The Right to the Highest Attainable Standard of Health

UN General Assembly A/RES/41/128 (UN Declaration on the Right to Development)

UN General Assembly, Report by the UN Special Rapporteur on Extreme poverty and human rights, A/67/278

UN Human Rights Committee, General Comment 29, States of Emergency CCPR/C/21/Rev.1/Add.11 (2001)

UN Human Rights Committee, General Comment 32: Right to Equality before Courts and Tribunals and to a Fair Trial, CCPR/C/GC/32 (23 August 2007)

UN General Assembly, Report of the Special Rapporteur on the question of torture and other cruel, inhuman or degrading treatment or punishment, A/56/156, 3 July 2001

\section{Domestic case law}

A (FC) and others (FC) (Appellants) v. Secretary of State for the Home Department (Respondent) [2004] UKHL 56

A and others (FC) and others vs Secretary of State for the Home Department[2005] UKHL 71

Ferreira v Levin NO and Others; Vryenhoek and Others v Powell NO and Others (CCT5/95) [1995] ZACC 13; 1996 (1) SA 984 (CC); 1996 (1) BCLR 1 (6 December 1995) para 49

R v. Bow Street Metropolitan Stipendiary Magistrate, Ex parte Pinochet Ugarte (No 3) [2000] 1 AC 147

S v M (CCT 53/o6) [2007] ZACC 18; 2008 (3) SA 232 (CC); 2007 (12) BCLR 1312 (CC) (26 September 2007)

van Alphen v. the Netherlands (Communication No. 305/1988), CCPR/C/39/D/305/1988, UN Human Rights Committee (HRC), 23 July 1990 